\title{
POLITICA PROZEI FRACTURISTE
}

\section{MIHNEA BÂLICI}

\author{
Universitatea Babeș-Bolyai, Cluj-Napoca
}

\begin{abstract}
This paper is aiming to analyze the prose of the early 2000s' young authors from an ideological and political point of view. Fracturism was a literary movement with anarchist and insurgent purposes, but the nature of their values was not clarified by the local literary criticism. This thesis suggests a redefinition of the anti-systemic attitude proposed by the Fracturists. Also, another objective is to clarify the relationship of Fracturist prose to the aesthetics' domain. In this sense, inconsistencies can be observed between the anti-postmodernist obsession of "The Fracturist Manifesto" and the literary works themselves. Moreover, the subcultural themes as used by the young prose writers become a means of self-promotion in the Romanian literary field from post-Communism.
\end{abstract}

Keywords: Fracturism, autofiction, postmodernism, post-Communism, literary field

Lucrarea de față propune o reconceptualizare a operelor prozatorilor care s-au format în cadrul mişcării fracturiste de la începutul anilor 2000. Autorii aduși în discuție sunt Ionuț Chiva, Alexandru Vakulovski, Adrian Schiop, Ioana Baetica, Ioana Bradea și Dragoș Bucurenci. In general, teoretizările care au fost vehiculate în discursul metaliterar despre fracturism au mizat pe dimensiunea angajamentului social al scriitorilor respectivi. Bătălia canonică dintre fracturiști și predecesori este bazată mai degrabă pe rațiuni de ethos literar decât de estetic: ceea ce milenariștii repudiază optzeciștilor este tocmai faptul că aceștia „s-au oprit la un spațiu (călduț, confortabil) al textului” (Vlădăreanu, 2004, 327), eliminând contextul social (traumatizant) din discuție. Această critică a „literaturității” generațiilor anterioare este realizată pe fundalul bulversant al tranziției, o perioadă de profunde discrepanțe socio-economice și de confuzie ideologică. Maturizarea politică din spațiul românesc 
neocapitalist a fost încetinită de un discurs anticomunist virulent, care a dus la estomparea stângii în dezbaterile publice. Astfel, dialogul politic postcomunist devine deficitar. In acest context bulversant, fracturismul este dificil de încadrat pe un compas ideologic. Oscilând simultan între anticomunism și anticapitalism, între euroscepticism şi critica traumei sovietice, între antinaționalism și anticolonialism, fracturiștii pretind că aleg calea unui anarhism radical, insurgent, atât la nivel sociopolitic, cât și cultural. În acest scop, manifestele literare realizate de aceștia promovează individualismul, anticalofilismul și autenticismul („efectul de ingenuitate” - Marius Ianuş), care se traduc în operele propriu-zise prin autobiografism (în poezie) și autoficțiune (în proză).

Făcând referire la cazul prozei fracturiste, teza aceasta are o miză dublă. În primul rând, este demonstrat faptul că prozatorii fracturiști nu oferă o critică totală a capitalismului sau a consumerismului, ci a sociocultural provocat de comunismul autohton. Mai exact, ceea ce îi ultragiază pe milenariști este discrepanța dintre „forma” capitalistă (superficială) și „fondul” comunist (osificat), care reprezintă structura de bază a societății tranziției. Acest paradox motivează alegerea autoficțiunii ca metodă literară principală: tânăra generație oferă, înainte de toate, o soluție la criza identitară a României aflată la răscrucea dintre două sisteme politice antitetice. În al doilea rând, teza argumentează că proza fracturistă, în ciuda anticonsumerismului pe care îl adoptă în mod manifest, operează cu o strategie de promovare tipic capitalistă. Legitimarea contraculturii și minoritarului din proza fracturistă nu reprezintă o valorificare cu miză etică a marginalului, ci un mecanism de marketing în bătălia canonică cu formula optzecistă. Deși autoficțiunea propune o lectură în cheie biografică, cu scopul accentuării efectului de autenticitate, scopul prozelor fracturiste este mai puțin cel de a reprezenta realitatea autohtonă brută și mai mult de a propune o alternativă estetică într-o lume literară ce începe să capete configurația pieței libere.

\section{Capitalism second-hand}

Observând că a existat o hegemonie a dreptei politice în plan cultural în anii '90, Mihai Iovănel postulează că „abia prin generația douămiistă agenda ideologică capătă consistență pe zona de stânga, chiar dacă inițial în forme anarhiste (Marius Ianuș) sau de respingere brută a «sistemului» (Elena Vladareanu, Ruxandra Novac, Domnica Drumea)" (Iovănel, 2017, 70). Deși această încadrare a fracturismului (numele enumerate aparțin aceleiași promoții) în sfera stângii este valabilă, Iovănel nu a adus 
nuanțări ideologiei acestei mișcări literare. În Manifestul fracturist, Marius Ianuș afirmă că, în plan politic, fracturismul este reprezentat de anarhism, dar explicitarea poziționării se dovedește ambiguă: „Anarhia noastră este revolta unor mai mult sau mai puțin falși marxiști care văd cum niște fasciști nenorociți ca Fukuiama pledează pentru o lume care distruge valorile spirituale ale umanității. Mai bine să distrugem noi lumea" (Ianuș, Crudu, 1998). Aici, termenii de „marxist” și „fascist” își pierd sensul propriu și sunt instrumentalizați retoric.

În ciuda teoretizărilor laxe, pot fi extrase două puncte relevante din Manifest. În primul rând, revolta se îndreaptă împotriva postmodernității și a societății de consum, în urma intrării bruște într-un sistem global capitalist. Totuşi, critica nu este adresată acestui sistem în sens larg, cât efectelor alienante ale acestuia în plan local (datorate contrastului dintre idealul occidental din mass-media și realitatea socială): „Pentru a vă oferi cel mai simplu exemplu al fracturii mesajului în lumea în care trăim: în registre diferite, e o fractură între un film mizerabil de la vreo televiziune și reclamele scîrboase care îl întrerup" (Ianuș, Crudu, 1998). Astfel, amendând societatea de consum, fracturismul atrage atenția la metabolizarea ineficientă a capitalismului în spațiul românesc. În al doilea rând, Ianuş îi acuză pe predecesori că ,au trădat poezia pentru un ideal mic-burghez” (Ianuș, Crudu, 1998), însă motivul acestei „trădări” este strâns legat de perpetuarea ierarhiilor instituționalizate în perioada comunismului. Similar, într-o anexă alocată fracturismului în proză din cadrul Manifestului, Ionuț Chiva diagnostichează atât prozatorii obsedantului deceniu, cât și pe cei optzeciști cu „sindromul Alecsandri (scriitorul care descrie iarna din camera sa călduroasă)" (Chiva, 2001), corelat cu privilegierea acestor scriitori în regimul predecembrist. Amendând viața literară contemporană, fracturismul atacă de fapt relațiile de putere moștenite din comunism. Aceste problematizări conturează un complex specific al periferiei est-europene: cel al unei societăți nepregătite pentru democratizare din cauza conservatorismului de fundal, dar dornică să adopte masca europenizării.

Proza fracturistă exemplifică acești vectori ai vieții sociopolitice locale. Eșecul a două macronarațiuni fundamentale din istoria postbelică a spațiului românesc (comunismul, apoi capitalismul) determină adoptarea unor formule literare directe și tranzitive, situate la granița dintre literar și non-literar, care să poată descrie realitatea iminentă a perioadei. Ca efect al neîncrederii în programul postcomunismului, prozatorii fracturiști nu sunt interesați de dinamicile macrosociale, colective, ci de nivelul intim, 
psihologic al acestor experiențe. Fracturiștii nu vor să creeze naraţiuni largi, cuprinzătoare, ci reprezentări atomizate, ale experiențelor personale. Autoficțiunea se dovedește a fi un spațiu fertil pentru prozatorii revoltați ai acestei promoții.

În acest context, atitudinea mefientă faţă de procesul europenizării și globalizării este un leitmotiv. De exemplu, Ionuț Chiva persiflează iluzia modernizării în 69: „nu știu dacă aș mai avea cui să-i explic că NU SUNTEM BULETINELE NOASTRE DE IDENTITATE și în nici un caz o turmă globalizată cu un Centru din ce în ce mai îndepărtat și prin aceasta mai simbolic" (Chiva, 2004, 23). Printre cei mai scandalizați de această stare de fapt se află basarabeanul Alexandru Vakulovski: dacă la început fetișizează România pentru poziția mai avantajoasă decât cea a Basarabiei în raport cu centrul european - „literatură, libertate, fericire, nu mint, așa vedeam eu România atunci” (Vakulovski, 2002, 42) - , autorul ajunge să vorbească despre ,începutul spulberării visului cu România, o babă ramolită care cică vrea să se dea la Europa și la NATO" (Vakulovski, 2002, 44). România apare adesea într-o poziție dezavantajată, de inferioritate față de forțele principale din spațiul euroatlantic. Ioana Baetica descrie o scenă în care Europa, personificată în postura femeiivampă, reușește să-1 seducă pe narator: „Dragă Europa, / Te-am visat azi noapte. [...] Mă excitasem, te voiam mai mult decât atât. Îmi șopteai la ureche cuvinte obscene" (Baetica, 2004, 47-48). Vakulovski se dovedește și mai dur în ceea ce privește personificările: „Încadrarea în societate? Care societate? Asta, care vrea să se încadreze în NATO, care-și ridică poala când cineva îi arată pula?” (Vakulovski, 2002, 86).

Faptul că globalizarea și europenizarea apar, pentru prozatorii fracturiști, ca fiind un miraj colectiv și simptomatic pentru perioada tranziției este unul dintre motivele pentru care acești autori promovează ideologia individualismului, grefată pe o mizantropie programatică. Astfel, revolta lor este plurivalentă. Fracturiștii sunt împotriva comunismului ${ }^{1}$, dar în același timp sunt cinici față de propaganda anticomunistă de după '89: „Ca-n O mie nouă sute optzeci și patru, cu minutele de ură, sau așa ceva... Dă-i unuia o icoană a tuturor relelor și vezi ce face. [...] Ia și tu orice liceu sau ia, mai degrabă, un liceu-internat sau ia România comunistă"

1. „Deși s-a tăiat ca o rîmă, Uniunea Sovietică există prin fragmentele sale, prin creiere mumificate. Comuniști sînt peste tot, sint majoritatea. Se numește altfel, totuși: naționalism și alte idei colorate la o sticlă de vodcă” (Vakulovski, 2004, 22-23). 
(Chiva, 2004, 89). În perspectiva fracturiștilor, cele două forțe geopolitice ce au marcat postbelicul sunt fețele aceleiași monede: „Uniunea Sovietică era pe de o parte, era răul, era pericolul omenirii, al libertății, iar tu, America, erai la celălalt capăt, erai libertate, erai pace, erai binele. [...] De fapt ești doar o proastă. Ca și Uniunea Sovietică” (Vakulovski, 2004, 28).

Cinismul fracturiștilor pornește de la ideea că societății românești îi este imposibil să depășească trauma comunismului, care a continuat să fie propagat la nivelul mentalităților, instituțiilor şi culturii. Din acest motiv, capitalismul nu a avut o apropriere organică, ci mai degrabă violentă, inautentică. României îi este repudiat entuziasmul cu care a adoptat economia de piață și brandurile internaționale. Ceea ce este deranjant pentru prozatorii fracturiști nu este sistemul consumerist în sine, ci superficialitatea lui. Tinerii autori se află între ciocan și nicovală: între un pol cultural de putere vetust, criticat pentru neangajare (și încă modelat de estetica optzecistă) și o cultură mainstream care copiază modelele occidentale. Teoretic, fracturiștii au încercat să creeze un nou autenticism, care să răspundă nevoilor noului Weltanschauung tranzițional. Practic, textele autorilor nu au respectat programul inițial. Centrul de interes al prozatorilor s-a aflat, de fapt, tot în interiorul literaturii: elaborarea unei noi formule care să poată fi comercializată în competiția literară locală.

\section{Contracultura ca strategie de marketing}

Fracturismul s-a născut ca o reacție la adresa monopolului literar al optzecismului, denunțându-i dimensiunea livrescă și edulcorantă: „Fracturismul desfide poezia optzecistă a realului” (Ianuş, Crudu, 1998). Totuşi, așezarea prozei fracturiste în opoziție cu paradigma postmodernistă ridică probleme. O specificitate formală sau teoretică clară a prozei fracturiste în peisajul literar extrem-contemporan nu este vizibilă. Autoficțiunea este un loc comun și în prozele optzeciștilor. De multe ori, în cadrul aceluiași text fracturist, fragmente diaristice, publicitare, narative, lirice și chiar textualiste se întrepătrund, conturând un proiect eterogen, experimental și, nu de puține ori, parodic-ludic. La fel ca postmodernismul, proza milenariștilor este foarte permisivă în alegerea tehnicilor literare, operând cu bricolaje de registre, formule și retorici diferite. Mihai Iovănel o include în categoria "realismului mizerabilist” (Iovănel, 2017, 142), opunând-o experimentelor metatextuale care au definit tradiția optzecistă. Elementele diferențiatoare sunt „deconspirarea convențiilor livrești și denudarea literaturii către o autenticitate (cuvântcheie al perioadei) contondentă și «nerușinată»" (Iovănel, 2017, 143). 
În primul rând, raportarea critică față de tradiția postmodernistă din România nu explică o delimitare clară față de programul generației anilor '80. Având în vedere tendința optzeciștilor de a se raporta critic la convențiile literare, deconstrucția livrescului este un element ce situează proza fracturistă mai degrabă în siajul postmodernismului românesc decât în antiteză față de acesta. În al doilea rând, problema autenticității în literatură naște probleme. Este îndeajuns ca o proză să mizeze pe pariul autoficțiunii pentru a fi „autentică”? Cum este posibilă delimitarea între înscenare biografică și „biografism în stare nudă” (Grațiela Benga)? $\mathrm{Nu}$ avem de a face cu un alt experiment postmodernist care îmbină textualismul cu biografismul, însă cu alte valențe?

Diferențele dintre prozele fracturiștilor și ale optzeciștilor se află, de fapt, în repertoriul tematic. Caracteristica literaturii milenariste este schimbarea mediului: marginalul, contracultura, scenele underground, sexualitatea deviantă și alte elemente refulate ale tranziției românești sunt puse în lumină programatic. Dacă la optzeciști „priza la real” reprezenta întoarcerea la universul domestic, cotidian, pentru fracturiști „obsesia realului se traduce prin căutarea experiențelor extreme, a poveștilor convingătoare" (Pârjol, 2016, 157). O întrebare esențială pentru analiza fenomenului fracturist în proză este următoarea: sunt aceste elemente centrale în textele respective? Este activismul prozei fracturiste veridic? Ce spune acest lucru despre politica prozei fracturiste?

Autoficțiunile fracturiste reprezintă mai degrabă tentative de conturare a unor persona literare decât o portretizare veridică a tranziției. Deși ele păstrează „efectul de real” prin apelul la elemente paratextuale (personaje reale, locuri deja existente ș.a.m.d.), discursul auctorial devine mai important decât problematica socială. Fiecare narator își construiește o personalitate recognoscibilă la nivel textual, iar proiectele schimbă semnul politicului în unul estetic. Chiar și în cazul celui mai „purist” dintre fracturiști, Alexandru Vakulovski, raportarea la mediul studențesc din România tranziției și la consumul de stupefiante cade în secundar față de căutarea unui mijloc de expresie autentic. Conturând „autoficțiunea unei generații măcinate de ură, sictir și revoltă, pentru care România nu e decât o promisiune înșelată" (Pârjol, 2016, 240), Vakulovski ajunge, în pizdeț (2002) și Letopizdeț (2004), să înșire crochiuri anticalofiliste, cinematografice, dure, care funcționează pe logica laconismului și tranzitivităţii: „O parte din lucruri trebuie spuse pe față, așa cum sunt ele. Când începi să-ți cauți alte cuvinte, «mai frumoase», realizezi că nu spui nimic din ceea ce crezi, din ceea ce ai vrut să spui inițial" (Vakulovski, 
2002, p. 60).

Ceilalți autori fracturiști propun înscenări autobiografice din ce în ce mai complexe, majoritatea fiind mai degrabă ludic-experimentali decât autenticist-provocatori. În cazul multor naratori fracturiști, există din start asumarea unei veleități de scriitor și a unei înscenări metatextuale. Personajul Ionuț Chiva afirmă în 69 că „,[a]m vrut să fiu un scriitor român de succes. Să vorbesc despre dramele și mîniile și debusolarea generației mele, generația prezervativ, "generația de sacrificiu», despre revoluții și mineriade \& stuff...” (Chiva, 2004, 18), în timp ce naratorul Adrian Schiop spune că intenționa „o poveste "profesionistă», care, înainte de a fi experimentală, cu voodoo-chestii, să fie citibilă, narativă: "decentă»" (Schiop, 2004, 99). Amândoi înscenează ratarea scriitoricească: Ionuț Chiva ajunge să rescrie o proză-snuff ficționalizată, absurdă, „o peliculă autarhică în care enunțarea, și nu enunțul (conținutul lui epic) este cea care contează" (Pârjol, 2016, 211), în timp ce Adrian Schiop nu dezvoltă teza socială a romanului său (homosexualitatea în România anilor '90), ci mai degrabă analizează detaliat raporturile de comunicare din grupul de prieteni din studenție, încât „tot conflictul [...] se petrece la nivel discursiv” (Pârjol, 2016, 230). Ioana Baetica joacă pariul autoficțiunii încercând să relegitimeze vulgaritatea dintr-un punct de vedere feminin, însă, trecând în paranteze capitalul de șoc pe care l-a avut apariția volumului Fișă de înregistrare (2004), ceea ce rezultă este un exercițiu estetic, în care naratorul pozează într-un intelectual care bifează toate clișeele prozei fracturiste. Cazul lui Dragoș Bucurenci în RealK (2004) este de asemenea grăitor: apelând la metoda gidiană a „manuscrisului găsit”, naratorul elaborează o serie de blogposturi care îmbină redarea propriilor experiențe psihotropice $\mathrm{cu}$ simularea textelor de informare a publicului despre consumul de droguri. În Băgău (2004), Ioana Bradea își aproprie metoda autoficțiunii fracturiste doar parțial. Aglomerarea de discursuri și registre nu sugerează un program autenticist, ci configurează atmosfera bruiată din lumea tabuizată a unui hotline bucureștean.

Această analiză relevă faptul că proza fracturistă își preia, în ciuda opoziției vehemente față de optzeciști, metodele și tehnicile literare din spectrul postmodernist. De altfel, este vizibil că preocuparea principală a prozatorilor fracturiști nu este neapărat de a sublinia problematici politice sau sociale, ci de a crea un discurs opozant la limbajul prețios și estetizant al literaturii canonice contemporane. $\mathrm{Cu}$ alte cuvinte, fracturismul în proză adoptă (aproape parodic) formele optzeciștilor și schimbă vocea narativă pentru a avansa în scena literară. Pentru a face 
acest lucru, naratorul vorbește dintr-o poziție care legitimează ceea ce este contracultural (scenele underground, fie că vorbim despre muzică, droguri sau interlopi) și marginal (sexualitate deviantă, poziție socială defavorizată) pentru a oferi o alternativă rentabilă la optzecismul care acaparase scena literară. Această strategie de marketing denotă faptul că fracturiștii doresc să se impună ca o nișă separată a vieții literare utilizând mecanismele de promovare ale capitalismului.

În concluzie, fracturiștii se poziționează împotriva capitalismului inautentic și a produselor de slabă calitate care populează scena de consum din România, dar nu sunt împotriva ideii de piață liberă și de democratizare/pulverizare a scenei culturale. În acest scop, ei oferă o nouă nișă care să poată fi comercializată, propunând o altă imagine a postmodernismului românesc: mai dură, mai conectată la realitatea socială, dar încă experimentală din punct de vedere tehnic, cu apetențe către estetizare și bovarizare sui generis, preocupată de conturarea unui discurs al „vieții de stradă”. Problemele sociale și politice, deși menționate în texte, sunt acaparate de jocul autoficțiunii, cristalizarea noului sistem de referințe și încercările vizibile ale fracturiștilor de a realiza prima nișă literară independentă din România postcomunistă. 


\section{Bibliografie:}

Baetica, Ioana, Fișă de înregistrare, Iași, Editura Polirom, 2004.

Bradea, Ioana, Băgău, EST-Samuel Tastet Éditeur, 2004.

Benga, Grațiela, Rețeaua. Poezia românească a anilor 2000, Timișoara, Editura Universității de Vest, 2016.

Bucurenci, Dragoș, RealK, Iași, Editura Polirom, 2014.

Chiva, Ionut,, "Fracturismul în proză," în "Suplimentul de marți” al ziarului Observator de Constanța, 5 iunie, 2001.

Chiva, Ionut, 69, Iași, Editura Polirom, 2004.

Ianuș, Marius, Dumitru Crudu, "Manifestul fracturist". Monitorul de Brașov, octombrie 1998.

Iovănel, Mihai, Ideologiile literaturii în postcomunismul românesc, București, Editura Muzeul Literaturii Române, 2017.

Pârjol, Florina, Carte de identități, București, Editura Cartea Românească, 2016.

Schiop, Adrian, pe bune/pe invers, Iași, Editura Polirom, 2004.

Vakulovski, Alexandru, pizdeț, Brașov, Editura Aula, 2002.

Vakulovski, Alexandru. Letopizdeț. Cactuși albi pentru iubita mea, Cluj, Editura Idea Design \& Print, 2004.

Vlădăreanu, Elena. „Ia-ți târfa și pleacă» sau câteva cuvinte despre ostilitate", în Generația 2000. Antologie, coord. Marin Mincu, Constanța, Editura Pontica, 2004. 